\title{
A MULHER NA TRADIÇÃO SATÍRICA NO LATIM MEDIEVAL E A MISOGINIA EM DE AMORE, DE ANDRÉ CAPELÃO
}

\section{THE WOMAN IN THE SATYRICAL TRADITION IN THE MEDIEVAL LATIN AND THE MISOGINY IN ANDREW THE CHAPLAIN'S DE \\ AMORE}

\author{
Pedro Carlos Louzada FONSECA ${ }^{1}$
}

\begin{abstract}
Resumo: No contexto do apogeu do fenômeno literário conhecido no mundo medieval como arte do amor cortês, peculiar por seu complexo ideário de idealização do amor feminino, verifica-se, contrariamente, um modo virulento de escrita crítica da mulher, quer em forma poética, tratadística ou mesmo misturando ambas. Modulando o cânone da crítica antiga contra o gênero feminino, esse tipo de escrita misógina foi responsável pelo aparecimento e atualização de um modo de literatura satírica composta no latim dos séculos XI e XII, fortemente comprometida com os ideais da misoginia tradicional. É na esteira desse tipo de literatura satírica misógina escrita no latim medieval que o presente artigo tem como objetivo analisar, de forma crítico-teórica e comparatista o polêmico, porque ambíguo nas suas intenções, De amore, tratado escrito por volta de 1185 por André, o Capelão ou André Capelão (Andreas Capellanus). $\mathrm{O}$ artigo pretende mostrar que a disposição misógina de Capelão constitui uma forma literária satírica da época conjugada ao cultivado idealismo do amor cortês. Mas, ao mesmo tempo, expressa a ideia da existência de um confronto estratégico da política misógina de estabilizar a figura feminina como um equilíbrio paradoxal perfeito, na medida em que servisse ao mesmo tempo para a difamação e para o elogio colocados à disposição das prerrogativas masculinas.
\end{abstract}

Palavras-chave: Literatura medieval. Sátira latina. Misoginia. André Capelão. De amore.

\begin{abstract}
In the context of the apogee of the literary phenomenon known in the medieval world as the art of courtly love, peculiar due to its complex ideals of idealization of feminine love, a virulent mode of critical writing of women is found, either in poetic form, or even mixing them both. Modulating the canon of ancient criticism against the feminine gender, this type of misogynist writing was responsible for the appearance and updating of a mode of satirical literature composed in the Latin of the XI and XII centuries, strongly committed to the ideals of traditional misogyny. It is in the wake of this type of misogynistic satirical literature written in medieval Latin that the present article aims to analyze, in a critically-theoretical and comparative way the controversial, because ambiguous in its intentions, De amore, a treatise written about 1185 by André the Chaplain or André Chaplain (Andreas Capellanus). The article intends to show that the misogynistic disposition of Chaplain constitutes a satirical literary form of the time combined with the cultured idealism of courtly love. But at the same time, it expresses the idea of a strategic confrontation of misogynist politics of stabilizing the female figure as a perfect paradoxical equilibrium insofar as it serves at the same time for the defamation and praise offered to male prerogatives.
\end{abstract}

Keywords: Medieval literature. Latin satire. Misogyny. Andrew the Chaplain. De amore.

Em pleno apogeu do fenômeno literário conhecido no mundo medieval como arte do amor cortês, peculiar pela expressão de uma complexa idealização do amor feminino, verifica-se um

\footnotetext{
${ }^{1}$ Doutor em Línguas e Literaturas Românicas pela University of New Mexico (USA). Professor do Programa de Pós-Graduação em Letras e Linguística da Universidade Federal de Goiás - Regional de Goiânia. E-mail: <pfonseca@globo.com>.
} 
modo de escrita crítica, quer em forma poética, tratadística ou mesmo misturando ambas, que desdobrou o cânone da crítica tradicional contra o gênero feminino. Esse modo de expressão foi responsável por um tipo de literatura satírica composta no latim dos séculos XI e XII, fortemente comprometida com uma revisitação e recontextualização das premissas e postulados da misoginia tradicional.

É na esteira desse tipo de literatura satírica misógina que surgiu o polêmico, porque a princípio ambíguo nas suas intenções, De amore (Sobre o amor), escrito por volta de 1185 por André, o Capelão ou André Capelão (Andreas Capellanus, 1150 - 1220). Sobre o autor, nada é muito conhecido por certo, embora possa ser razoavelmente cogitado que ele esteve associado à corte real francesa da sua época e conhecia a condessa Marie de Champagne nos anos de 1180.

A arriscar-se numa generalização, embora preliminar, pode-se dizer que o De amore, de André Capelão é, de certa forma, uma obra feita ao feitio paródico e satírico, repleta de críticas e gozações acerca dos refinamentos do amor cortês ou da cortesania amorosa ao modelo medieval do século XII, cheia de questões, respostas e modelos de debates sobre temas ligados à prática amorosa, tudo isso colocado dentro de uma estrutura geral de composição que lembra vagamente a Ars amatoria (Arte de amar), de Ovídio (OVID, 1982).

Dessa forma, em direção emuladora a Ovídio, André Capelão compõe o seu De amore, que se apresenta estruturado em três livros. O Livro I consiste numa elaboração imitativa da arte de cortejar, enquanto que no Livro II o autor trata, dentro desse mesmo tema do amor cortês, da arte de reter e conservar esse sentimento (figura 1). No Livro III, André Capelão carrega em grau paroxístico o teor de uma radical atitude crítica e satírica, de cunho professadamente misógino, que perpassa toda a obra do autor. Nele, vazado num discurso de extrema denegação e de acusação maledicente dos defeitos e vícios atribuídos à mulher, o autor expõe as suas ditas justas razões do porquê não se deve amar uma mulher. 
Figura 1 - Cavaleiro-poeta em serventia cortês a uma dama

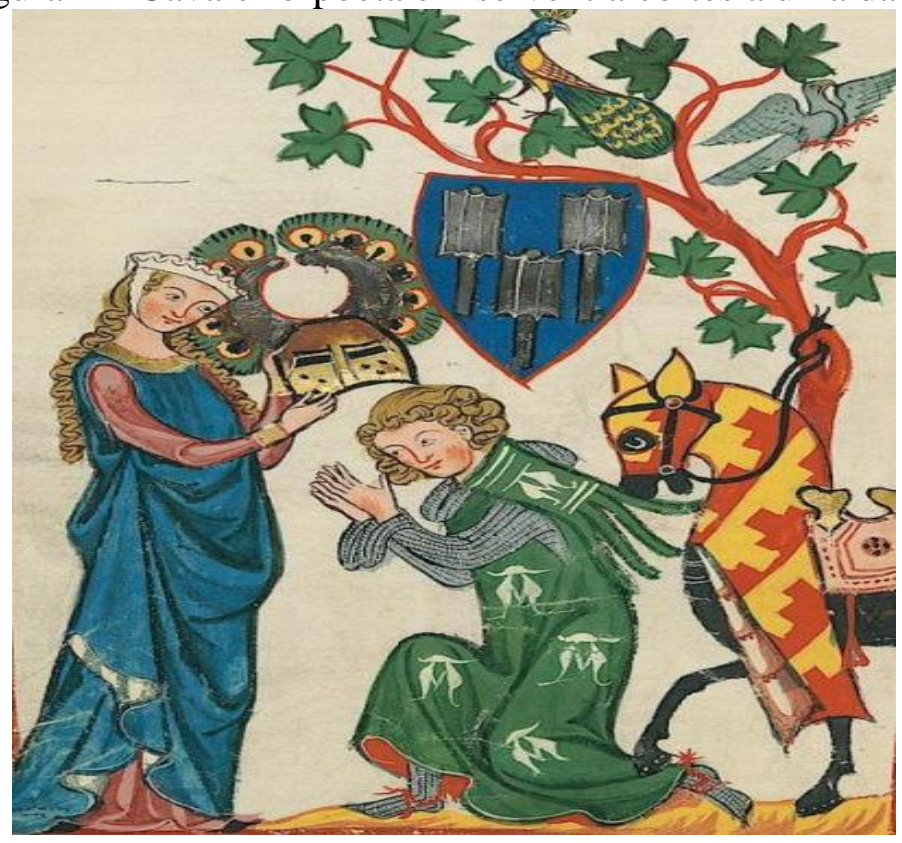

Fonte: Der Schenk von Limpurg (ou Walther I, fl. 1230s-1240s, ou um de seus filhos, Walther II ou Konrad I). Nota-se que simbolicamente ela dispõe-lhe a máscara da discrição, um dos códigos prescritivo da cortesania. Ilustração do Codex Manesse, Zurique, entre 1305 e 1315. UB Heidelberg, Cod. Pal. germ. 848, fol. 82v. Cortesia da Universidade de Hiedelberg e Wikimedia Commons. Disponível em: https://www.purplemotes.net/2015/06/21/de-amore-andreascapellanus-rhetoric/

Embora, no prefácio do livro, o autor tenha prometido apresentar, ao modelo do Remedia amoris (Remédios do amor), de Ovídio (OVID, 2001), um lenitivo ou um guia salutar para remover os tormentos desse sentimento daqueles que se acham vítimas dos seus desafetos, isso não acontece na prática, porque o livro é mais uma forma de repúdio imediato ao amor do que um consolo e cura para o desamor. Imbuído desse propósito, o Livro III do De amore, de André Capelão, discorre os seus argumentos misóginos para provar porque não vale a penar amar uma mulher, construindo um discurso composto de uma miscelânea de argumentos religiosos, morais e prudenciais, tais como, o amor sexual ofende a Deus, danifica as amizades, prontifica a violência e os piores perjúrios e outros tantos crimes mais de semelhante danação. Esse mesmo amor escraviza e faz o homem perder a sua reputação pública, trazendo-o para a influência do mal, debilitando-o ainda no corpo e na alma.

Depois de todo esse arrazoado misógino, André Capelão parece dar a entender que, apesar de ele ser de parecer que a fornicação com uma mulher desfigura a dignidade do homem, ele se contém em proceder a uma análise da natureza e da condição da mulher para provar que essa natureza e essa condição feminina são, na verdade, as causadoras dessa decadência do homem 
em atividade de amor carnal com uma mulher. Diz André Capelão que não fará essa análise porque isso seria ampliar-se por demais na discussão de um tópico que, além de insípido e tedioso, poderia ser interpretado negativamente como uma condenação da Natureza (De amore, 1982, III. 52-53), ${ }^{2}$ ponto de vista esse compartilhado por São Jerônimo em Adversus Jovinianum (Contra Jovinianus), em que o santo parafraseia São Paulo quando diz da aquiescência ao casamento apenas como atitude a ser adotada para se evitar que a natureza feita por Deus não seja condenada (JEROME, 1892, I. 8, p. 779-907).

Entretanto, André Capelão, páginas depois dessa passagem em que se declara não poder ir contra os desígnios da Natureza, não se contém na sua promessa e se lança em indiciamentos, os mais perversamente misóginos, contra a maneira de ser que comenta ser inerente à mulher. Tais invectivas, presumivelmente deliberadas, as quais percorrem praticamente toda a extensão do livro, se qualificam como as mais exasperadoras na perspectiva da mais aferrada postura ideológica marcadamente misógina, pois se caracterizam como totalizadoras por seu reducionismo discriminatório e incriminatório que condena toda mulher a essencialismos materiais, morais e espirituais dignos de figurar num manual de misoginia ao estilo dos das caças às bruxas medievais.

Embora os exageros retóricos permeiem o tratado como um todo, esse modus operandi para a denegação da mulher, caracteristicamente formado por uma linguagem totalitarista alcança um ponto máximo nas partes examinadas do citado Livro III. Na verdade, o livro parece dar a entender que toma o seu tempo e esmero em sedimentar ad aeternum, em determinados pontos de discussão, os princípios que constituem a negatividade da formação do feminino. Diante do trato dessa estridentemente triste misoginia, é de finalmente se cogitar se essa postura contra a mulher não seria o correlato de uma postura contra o amor, ou melhor, o amor cortês, podendo-se nesse caso pensar se tudo o que o autor diz da mulher não foi exatamente o que ele pensou ser a mulher na realidade, pois nos Livros I e II, ele havia apenas flertado com a psicologia e a sexualidade femininas. Finalmente, diante dessa realidade escritural, cuja ambivalência parece não poder ser desconsiderada inexistir, alguma coisa de certa existe no $D e$ amore, de André Capelão, qual seja, a sua intenção satírica buscada no retrato da realidade feminina enquanto objeto de um desejo amoroso centrado no masculino e nas suas inerentes derrogações misóginas.

\footnotetext{
${ }^{2}$ Andreas Capellanus. Andreas Capellanus on Love. Ed. e trad. P. G. Walsh. London: Duckworth, 1982. Todas as referências a passagens citadas de De amore serão, no decorrer deste artigo, a exemplo da presente citação, para efeito de melhor propriedade de localização, referidas apenas em relação ao respectivos livros, capítulos e seções em que se encontram. $\mathrm{O}$ mesmo procedimento será adotado com relação às fontes de referência clássica sobre o assunto nele tratado
} 
E para provar essa centralização misógina decorrente das prerrogativas androcêntricas, o De amore, de André Capelão, oferece inúmeras passagens que servem como exemplo dessa situação, como a que ocorre no Livro II, em que o autor lembra o tão glosado tema da literatura medieval misógina conhecido como topos do padrão duplo, ou seja, a consideração de dois pesos e duas medidas para tratar de direitos e deveres que conjuntamente dizem respeito ao homem e à mulher (CAPELLANUS, 1982, II. 6. 15).

A seguir na discussão do assunto, no Livro II. 6. 15, de De amore, diz André Capelão que, desde a investigação do primevo pecado, pode ser considerado o que deveria ser feito se uma mulher quebra a fidelidade ao seu amante. Expõe que a duradoura opinião de algumas autoridades tem procurado reivindicar que as mesmas convenções estabelecidas para o caso de um homem traidor devem ser inteiramente preservadas no caso de uma mulher traidora, conforme pode também ser lido na Epistola 77, ad Oceanum, de São Jerônimo (JEROME, 1892, III, p. 391-402). Apesar dessa consideração paritária, num verdadeiro tour de force característico dos costumeiros julgamentos discricionários da misoginia, considera André Capelão que, embora essa opinião seja muito antiga, a sua idade não deveria ser reverenciada porque lança sobre todos o maior dos erros. E não perde mais tempo em comentar sobre esse aludido grande erro.

Continuando, na seção 16 desse mesmo capítulo 6 do Livro II de De Amore, a consideração do assunto acerca de uma mulher amar duplamente, André Capelão comenta que Deus proíbe que nunca deveria ser proclamado perdão para uma mulher que não se envergonhasse de satisfazer os desejos de dois homens. Entretanto, no caso do homem esse perdão é condicional.

No capítulo 19 desse mesmo Livro II de De Amore, André Capelão chega mesmo a recusar um remédio para quem ama esse tipo de mulher, repetindo, na seção 28 do Livro III, que liberdades sexuais são permitidas aos homens por causa da sua imprudência (audacia), mas, se conferidas às mulheres, acabam por reduzi-las à condição de prostitutas. Finalmente, na seção 17 do capítulo 6 do Livro II, de forma arrogantemente misógina, pondera que, se o retorno dessa mulher transgressora por duplicidade amorosa ao seu antigo amante for levado em consideração, é tido como bastante vergonhoso para ele deleitar-se com os abraços dela daí para frente, porque ele pode chegar à conclusão, com toda a certeza, de que o amor dela por ele de forma alguma continuará sendo o mesmo. Então, conclui retoricamente André Capelão perguntando a razão pela qual o antigo amante deveria recolocar a sua afeição nesse tipo de mulher irrecuperável. 
Conforme comentando anteriormente, o Livro III de De amore radicaliza de forma totalitária o ser e a condição femininos como realidades imprestáveis para a dedicação amorosa do homem, juntando na retórica do seu discurso aversão e raiva à mulher, elementos considerados como dois ingredientes básicos para identificar a misoginia. Assim, nas seções 62-64 desse livro, é discutido acerca dos males que o amor faz à inteligência e à razão do homem sábio. Nesse sentido, diz André Capelão, de modo bastante semelhante ao que sobre o assunto São Jerônimo comenta em Adversus Jovinianum, que outra razão pela qual ele adverte o homem a não amar é porque, devido à paixão amorosa, a sabedoria dele torna-se desalojada da sua função (JEROME, 1892, I. 49, p. 779-907).

No âmbito desse comentário, continua dizendo que não importa o quão cheio de saudável senso esse homem seja, porque, uma vez seduzido para o intercurso sexual, ele não pode observar a moderação e se desfaz da sua sabedoria de controlar tendências a indulgências sexuais ou de conter as suas letais atividades. Na verdade, continua André Capelão dizendo que os inteligentes são ditos crescerem mais dementes com amor e saciam mais avidamente os desejos da carne do que aqueles com menos conhecimento para guiá-los. E, para exemplificar a situação, cita o caso de Salomão, dizendo que nenhum homem teve mais completa ou maior sabedoria do que ele, entretanto ele pecou por indulgência sexual sem limite e, por meio do amor de mulheres, não temeu cultuar deuses estrangeiros.

Lembra também o caso, bastante citado da relação famosa de homens destruídos por uma mulher, do rei Davi, dizendo que, apesar de não ter havido nenhum outro profeta de maior sabedoria celebrada do que ele, ainda assim ele teve inúmeras concubinas, cobiçou de forma abominável a esposa de Uriah, debochou dela em adultério e, como a um traiçoeiro assassino, matou o seu marido. Concluindo esse arrazoado sobre o pernicioso amor feminino, André Capelão, concertando com os comentários de Walter Map sobre Salomão e Davi na sua Dissuasio Valerii ad Ruffinum philosophum nec uxorem ducat (Dissuasão de Valerius a Ruffinus para não tomar uma esposa) (1983. p. 287-331), e com o que São Jerônimo diz sobre esses exemplos na sua Epistola 22, ad Eustochium (JEROME, 1892, p. 100-137), pergunta qual simples homem amante poderia controlar a sua luxúria, uma vez que homens tão famosos por seu suporte de tão grande instrução em sabedoria falharam frente ao amor por mulheres que causou a sabedoria deles esquecer a sua função, tornando-os inábeis para controlar a sua indulgência sexual.

Nas seções 65-69 do Livro III, André Capelão comenta sobre a naturalmente impossível reciprocidade do amor da mulher, a sua ganância material no trato dos seus afetos, a sua desleal inconstância afetiva e a vil vulnerabilidade moral dos seus sentimentos afetados por interesses 
materiais apenas. Porque, conforme pode ser lido em Ars amatoria (OVID, 1982, II. 279), e em Amores (OVID, 1982, I. 8), de Ovídio, é do feitio da mulher procurar por riqueza no amor e não dar a seu parceiro o consolo de que ele gosta. E ninguém deveria se surpreender diante disso, porque está na natureza dela.

André Capelão, comentando sobre a desleal inconstância afetiva feminina, diz que não existe mulher que possa ser encontrada que esteja ligada ao amante com tal afeição e firme constância que ela permanecerá leal ao seu amor se algum homem aproximar-se dela com a menor oferta de presentes. Explica que essa inconstância do amor feminino ocorre por causa da vil vulnerabilidade moral da mulher que tem os seus sentimentos afetados pela ganância de coisas materiais.

Por fim, concluindo a discussão desse tópico sobre a vergonhosa vulnerabilidade da mulher motivada por interesses pecuniários apenas, diz André Capelão que não existe nenhuma mulher viva de distinção de sangue ou abençoada com posição e com abundância de riqueza que uma oferta de dinheiro não quebre a sua virtude, podendo, portanto, ser corrompida pela extensão material da riqueza, mesmo sendo de um corrupto ou de um homem ordinário. A razão disso, conclui André Capelão, é que nenhuma mulher nunca se considera rica, assim como o embriagado nunca pensa que já teve o suficiente para beber. Mesmo se a terra e a água fossem inteiramente transformadas em ouro, finaliza ele, a avareza de uma mulher dificilmente poderia ser diminuída por isso.

A seguir, na seção 70 do Livro III, André Capelão continua a satirizar misoginamente os vícios femininos, sendo praticamente todos eles coincidentes com os tipos de pecados capitais sancionados pela Igreja. Dessa forma, diz que toda mulher é por natureza não somente avarenta mas também invejosa caluniadora de outras mulheres, usurpadora, escrava da sua barriga, inconstante, tortuosa na fala, desobediente, rebelde contra as proibições, casada com o vício da vaidade, ávida de vanglória, mentirosa, uma bêbada, uma linguaruda que não pode manter um segredo. Nessa ordem nominal dos vícios da mulher, André Capelão faz uma exposição dissertativa sobre cada um deles, abordando os aspectos que considera mais severos para comentar a malignidade de cada vício aludido.

Seguindo nessa explanação, André Capelão adota o seu costumeiro tom retórico figurativo e proverbial, dizendo da avareza feminina que é possível mais facilmente raspar um pedaço da inquebrável pedra-ímã com a unha do que, por meio da sabedoria humana, obter da mulher alguma coisa, por sua livre vontade, das suas escondidas economias. Então, conclui que nenhuma mulher está jamais ligada em tão ardente amor a um homem que ela não devote todo o seu cérebro para sugar a riqueza do seu parceiro. 
O próximo vício da lista, comentado por André Capelão nas seções 73-74 do Livro III, é a inveja. Discorre sobre ele que, como regra geral, toda mulher é também conhecida por ser invejosa, sempre consumida por ciúme da beleza de outra e descontente com o seu quinhão material. Ao terminar nessa explanação sobre a inveterada inveja feminina, André Capelão diz que é mesmo quase inconcebível que uma mulher deva elogiar o caráter moral e a beleza de outra e que, se acontece de ela elogiá-la em alguma coisa, ela imediatamente acrescentará uma crítica de alguma outra coisa para cancelar o elogio que anteriormente fez.

Na sequência dos vícios aludidos na lista feita por André Capelão, o próximo deles a ser comentado, nas seções 75-77 do Livro III, é a calúnia. Diz ele que, com muita consequência, pode-se arrazoar que a mulher é mesmo uma grande caluniadora, porque a calúnia é o resultado do exercício da inveja e do ódio. Continua André Capelão a sua dissertação condenatória dizendo que toda mulher acredita que ela esteja aumentando a sua glória e o seu próprio bom nome se ela procura diminuir os elogios de outras mulheres, e complementa essa ideia dizendo que isto é uma clara indicação a todos de que existe pouca sabedoria remexendo dentro das mulheres, porque cada um no mundo está ciente da regra geral e constante de que a calúnia somente danifica o bom nome e fere a reputação do caluniador.

Comentando sobre o vício da ganância feminina, André Capelão, nas seções 78-79 do Livro III, diz que toda mulher é também deformada pelo vício da ganância, pois ela esforça cada tendão seu para roubar todas as posses, não somente de outros homens, mas também do seu marido, com quem ela felizmente se casou. Tal é a ganância que prevalece numa mulher. De fato, pondera André Capelão sobre esse tópico comentando que uma mulher pensa que recusar presentes a todos e manter zelosamente coisas ganhas por meios justos ou faltosos é a maior das virtudes e uma qualidade que todos deveriam louvar. Remata sobre esse indecente procedimento feminino dizendo que nenhuma mulher é exceção a essa regra, nem mesmo uma rainha.

O próximo vício feminino censurado de forma misoginamente satírica por André Capelão, nas seções 80-82 do Livro III, é a gula. Sobre esse vício diz que uma mulher é habitualmente escrava da sua barriga, pois não existe nada que a enrubesça em provar, se ela tiver certeza, da comida excelente. André Capelão, a propósito da gula feminina, teologiza esse pecado dizendo que ele pode ser referido a Eva, a primeira mulher. Embora feita pela mão de Deus, tal fato não a fez em nada mais temerosa em tomar o fruto proibido, e ela mereceu ser expulsa da sua casa no Paraíso por causa da sua voraz barriga. Depois dessas ponderações, André Capelão, no seu usual tom proverbial totalitário acerca da misoginamente satirizada e denegrida realidade feminina, conclui que se pode considerar, então, como regra geral o fato de 
que de uma mulher qualquer coisa pode ser obtida se se tiver o cuidado de dar-lhe frequentemente finas refeições.

A seguir, nas seções 83-88 do Livro III, André Capelão comenta sobre a inconstância feminina considerada como regra geral, dizendo que não existe nenhuma mulher firmemente determinada em alguma coisa que a sua credibilidade não seja logo dissipada por uma leve persuasão de alguém. Isso porque a mulher, continua André Capelão, é como cera derretida, sempre pronta para assumir nova forma e para ser moldada pela marca do selo de alguém. Essa ideia de que a mulher possui uma natural moleza de constituição estabeleceu-se definitivamente na Idade Média misógina por meio das considerações etimológicas de Santo Isidoro de Sevilha (ISIDORE OF SEVILLE, 1962). Mais tarde, Marbodo de Rennes (MARBODUS, 1844-180, 171, col. 1698-1699) associou a formação da mulher à cera que se molda facilmente, podendo aqui ser considerada a insinuação de a mulher ser passível de ser marcada por selos fálicos (JACQUART; THOMASSET, 1988, p. 38).

Continuando no seu comentário sobre a inconstância e a mutabilidade da mulher, André Capelão diz que nenhuma mulher poderia fazer um homem tão confiante na promessa dela que a sua intenção e propósito dessa promessa não sejam vistos mudarem na próxima promessa dela. A mente de nenhuma mulher, continua ele, permanece imutável por uma hora, tanto que Martianus razoavelmente diz que, em se tratando de acordo com as mulheres, não se deve demorar, porque elas são sempre inconstantes em suas maneiras. Nota-se aqui, no discurso de André Capelão, uma reminiscência das celebradas palavras da Eneida na passagem em que Mercúrio urge Eneas a deixar Dido, porque as mulheres são inconstantes. Entretanto, André Capelão, de forma surpreendente, atribui essa fala a Martianus Capella (VIRGÍLIO, 2004).

Continuando no seu arrazoado sobre a inconstância e a mutabilidade do caráter feminino, André Capelão satiricamente recomenda que o homem deve sempre manter a sua bolsa preparada quando confrontar as promessas de uma mulher, e acrescenta que o velho provérbio parece não tolerar nenhuma exceção, no caso das mulheres, quando diz que uma vez que se está pronto deve-se evitar atrasos porque a procrastinação nunca compensa (WALTHER, 19631969, 31438).

Para André Capelão, ligado à inconstância e à mutabilidade do caráter da mulher, está a sua capacidade de engano, porque é sabido que tudo o que ela fala é de forma enganosa, visto que tem sempre ideias diferentes das palavras que diz. Isso porque uma mulher não crê no homem como amigo, acreditando que todos são, ao final das contas, enganadores. Então, ela continua sempre na sua proposta enganadora, e tudo o que ela fala é dito com um coração falso e com uma mente ambivalente. 
Acrescenta que é por isso que o homem deve se certificar de sempre manter os seus propósitos íntimos escondidos da mulher, não devendo revelar a ela os seus pensamentos escondidos, para que dessa forma ele trapaceie malícia com malícia, e repila o engano dela. Como exemplo máximo dessa situação, cita o caso de Sansão, do qual todos os homens conhecem o seu caráter honesto, mas é sabido que, devido não ter podido esconder os seus pensamentos íntimos de uma mulher, foi traído pelo enganoso coração dela, conforme pode ser lido em Juízes 16: 15, e na Epistola 22, ad Eustochium, XII, de São Jerônimo (JEROME, 1892, XII, p. 100-137).

Nas seções 89-91 do Livro III, André Capelão comenta sobre outro vício da mulher, a desobediência, não menos censurável que os defeitos anteriores a ela impingidos. Sobre esse vício coloca que toda mulher luta contra qualquer proibição com toda a força do seu corpo, ressoando o que é comentado em Amores, de Ovídio (OVID, 1982, III. 4-17), e em Walther (1963-1969, 29695).

Continua André Capelão a discorrer sobre o afã feminino de transgredir a proibição, lembrando o caso prototípico de Eva, retoricamente perguntando se não foi ela, a primeira mulher feita pelas mãos de Deus, que morreu e perdeu a sua glória de imortalidade pelo pecado da desobediência, por seu culposo arrastar de toda a sua posteridade para a destruição mortal. Depois disso, recomenda ironicamente pragmático que, se alguém quiser que uma mulher faça alguma coisa, com certeza conseguirá o seu intento se pedir para ela fazer o contrário.

A seguir, nas seções 92-93 do Livro III, André Capelão aborda o vício do orgulho feminino, mais uma instância em que os vícios condenados pelo autor coincidem, na maioria dos casos, com os pecados capitais da religião cristã. Sobre o orgulho, é comentado que ele danifica o sexo feminino porque, quando uma mulher é despertada por algum incentivo ao orgulho, ela não pode controlar a sua língua e mãos com feitos e palavras abusivas, e tomada de raiva, imprudentemente faz todos os tipos de maldade. Nota-se aqui que o orgulho se apresenta associado à ira, outro pecado capital que não tinha até esse ponto sido discutido.

Nas seções 94-96 do Livro III, André Capelão continua conferindo na mulher os males do seu vício da arrogância. Nesse sentido, diz que toda mulher parece desprezar as outras, sendo isso um traço claramente provindo da simples arrogância, porque nenhum homem poderia menosprezar outro exceto por elevado orgulho. Diz que as mulheres, tanto as bruxas alquebradas quanto as jovens garotas esticam cada nervo para elogiar a sua própria beleza, e que as palavras do sábio, que comenta que desprezo bruto e orgulho existem no carro da beleza, claramente provam que esse hábito também resulta da simples arrogância, conforme pode ser lido em Fasti [Sobre o calendário romano], de Ovídio (OVID, 1977-1989, I. 419), e em Walther 
(1963-1969, 8874). Então, conclui André Capelão acerca desse tópico da arrogância feminina dizendo que é quase evidente que a mulher não pode estar em plena posse de um caráter digno, porque, diz o ditado que, quando a arrogância está presente, ela arruína todos os modos justos (WALTHER, 1963-1969, 12465).

Ao lado da arrogância, André Capelão coloca o vício feminino da vanglória, dizendo que ninguém pode achar uma única mulher no mundo que não seja encantada, mais que tudo, pelo elogio das pessoas e que não acredite que todas as palavras ditas sobre ela são direcionadas ao seu louvor. Traça essa falta feminina, como tantas outras vistas anteriormente, a partir da primeira mulher, Eva, quando ela tomou a comida proibida para que fosse capaz de ter o conhecimento do bem e do mal. Ainda discorrendo sobre a ostentação da vanglória como um vício inerente à natureza feminina, conclui, no seu costumeiro modo sentencioso, dizendo que a ostentação é um tipo de coisa que a vanglória procura por si própria.

Abordando o vício da mentira nas seções 97-98 do Livro III, André Capelão emite a sua sentença totalitária de que todas as mulheres são igualmente conhecidas como mentirosas, porque não existe nenhuma mulher viva que não faça pretensão do que não é verdadeiro, e inventa mentiras com incansável ingenuidade. Uma mulher mentirá sob juramento mil vezes por alguma pequena vantagem, e inventa mentiras sem fim para o menor ganho.

E, na verdade, continua comentando André Capelão sobre o vício da mentira nas mulheres dizendo que elas escravizam para manter todas as suas mentiras por engano, e são vaidosas por inventar coisas não verdadeiras contra as outras senhoras com elaborada falsidade.

A seguir, na seção 99 do Livro III, André Capelão aborda o vício da bebedeira feminina, dizendo que todas as mulheres são beberronas, afeiçoadas em beber vinho, e que nenhuma delas fica envergonhada de beber o melhor Falernian na luz do dia em companhia de uma centena de colegas matronas. Na Sátira VI, de Juvenal (1958, 430), essa marca de vinho é referida a propósito do episódio de uma mulher vomitando tal preciosa bebida.

O vício seguinte a ser criticado por André Capelão é a lamentável incontinência da fala feminina. Assim, nas seções 100-101 do Livro III, ele diz que todas as mulheres são também de língua solta, porque nenhuma delas pode refrear a sua fala viciada em injuriar as pessoas ou em gritar alto o dia inteiro igual a um cão latindo, lamentando a perda de um único ovo e perturbando a vizinhança inteira por causa de uma ninharia. Dessa forma, diz André Capelão que a língua e a respiração de uma mulher nunca poderiam ficar exaustas de tanta falação.

A seguir, dando a entender estar associado a esse vício compulsivo de a mulher não poder parar de falar, André Capelão, nas seções 102-103 do Livro III, comenta que nenhuma mulher pode manter um segredo, porque quanto mais ela é mandada manter alguma coisa em segredo, 
tanto mais ela avidamente se esforça para contar a todo mundo. André Capelão analisa essa compulsão feminina para a indiscrição generalizando que um segredo confiado a uma mulher parece queimá-la por dentro, se ela primeiramente não expõe as confidências tão desastrosamente depositadas nela. Conclui que não se poderia prevenir as mulheres de agirem dessa forma mandando-as fazer o oposto, a regra-de-bolso comentada anteriormente, porque todas elas têm o maior prazer em fofocar sobre alguma coisa nova. Então, o mais aconselhavelmente certo é manter todo segredo longe de toda mulher.

Na seção 104 do Livro III, André Capelão aborda talvez o mais derrogatório, porque pejado de censura e de condenação moral e religiosa, dos vícios conferidos à mulher, qual seja, o pecado da luxúria. Nesse sentido, diz que toda mulher no mundo é também lasciva, porque uma mulher pode ser eminente em distinção de classe e um homem, o mais baixo e desprezível, mas se ela descobre que ele é sexualmente viril, não recusa dormir com ele. Ressoando o que Juvenal diz sobre o assunto na Sátira VI (1958, 115-132), diz André Capelão, rematando a sua opinião sobre a terrível incontinência libidinosa feminina, que nenhum homem embora viril poderia de modo algum saciar por completo desejo sexual de uma mulher.

Continuando a dissertar sobre a irrefreável lascívia feminina, diz André Capelão nas seções 105-106 do Livro III, que nenhuma mulher está ligada a um amante com tão casta lealdade, ou está também unida ao seu marido que ela não acolha outro homem como amante, especialmente se ele for rico, podendo-se ver a luxúria na companhia de uma mulher com o mais flagrante desejo.

Ainda na sua opinião sobre a luxúria da mulher, André Capelão, que a exemplo das tantas outras considerações por ele emitidas acerca da realidade feminina - que ele quer que tenham força de verdadeira lei ou princípio regedor da sua natureza e da sua conduta -, postula que nenhuma mulher neste mundo é tão fiel ou tão compromissada com algum noivado que, se um luxurioso amante aparece e a provoca com as suas habilidades e persistência para desfrutar do amor, ela não se preocupa, de forma alguma, em rejeitar o pedido dele ou defender-se contra as suas aproximações, uma vez que ele tenha usado de pesada pressão.

No seu costumeiro modo totalizador a adquirir peso de um verdadeiro postulado, André Capelão diz que essa vergonhosa disponibilidade feminina para o adultério ou licenciosidade sexual é mesmo uma regra que não falha no caso de nenhuma mulher, porque pode-se normalmente notar que, mesmo a mulher reputada como distinta e afortunada por ter um honrado amante ou excelente marido, ainda assim ela procura por lascivos intercursos com outro homem. E conclui no seu trágico tom condenatório terrivelmente misógino que uma mulher se comporta assim porque ela é praguejada por um obsessivo desejo sexual. 
Coroando todo esse arrazoado praguejador dos mais hediondos vícios atribuídos ao modo de ser da mulher, André Capelão radicaliza a realidade feminina, seguindo a mais aferrada tradição misógina do mundo antigo e medieval, como essencialmente malévola e causadora de malignidades ao homem. Dessa forma, nas seções 107-109 do Livro III, postula que o sexo feminino é inteiramente disposto a todo mal e que toda mulher comete destemida todo pecado maior do mundo sob um pequeno pretexto, e a sua mente prontamente dobra-se a todo mal sob a mínima pressão de alguém. Continua André Capelão dizendo, levando agora o seu arrazoado para a perspectiva da conferição na mulher de uma inata tendência para colocar-se como objeto do propiciar de forças ocultas e superstições perversas e malignas, que não existe mulher viva no mundo, mesmo sendo uma imperatriz ou uma rainha, que não devote toda a sua vida a portentos e a diferentes modos de adivinhação do futuro, como os pagãos fazem. A sua mente crédula, continua ele, é obcecada pelo paganismo, e ela diligentemente pratica as infinitas perversidades da astrologia.

De fato, diz André Capelão, ainda comentando sobre o assunto, não existe nenhuma tarefa que a mulher faça sem esperar a chegada do dia e da hora apropriada, e sem inaugurá-la com funesta arte. E para coroar esse arrazoado sobre o poder da inclinação perversa e malsã da mulher às forças supersticiosas do paganismo, André Capelão lembra o caso de Salomão que, na sua grande sabedoria, conhecendo como conhecia toda a perversidade e crimes da mulher, fez o pronunciamento geral e máximo acerca dos seus vícios e depravação de que, na mais pura verdade, não existe mesmo uma boa mulher, conforme pode ser lido em Eclesiastes 7: 29.

Conforme pode ser observado nessa breve leitura dos vícios e defeitos da mulher expostos no Livro III de De amoré, de André Capelão, em contraposição ao que pode ser lido nos livros I e II que integram a obra, a disposição misógina de Capelão constitui uma forma literária satírica da época aposta ao cultivado idealismo do amor cortês. Mas, ao mesmo tempo, expressa a idéia da existência de um confronto estratégico da política misógina de "estabilizar" precariamente a figura feminina num estado de equilíbrio paradoxal perfeito, na medida em que tal equilíbrio pudesse servir ao mesmo tempo para a difamação e para o elogio da mulher, sempre colocados à disposição das prerrogativas masculinas.

\section{Referências}

CAPELLANUS, Andreas. De amore libri tres. Disponível em: http://www.thelatinlibrary.com/capellanus.html Acesso em: 07 jun. 2018. Andreas Capellanus on love. Ed. e trad. P. G. Walsh. London: Duckworth, 1982. 
BLOCH, R. Howard. Misoginia medieval e a invenção do amor romântico ocidental. Trad. Claudia Moraes. Rio de Janeiro: Editora 34, p. 180-206.

HOLY BIBLE. Tradução da vulgata latina. Belfast, ed. de 1852.

ISIDORE OF SEVILLE, St. Isidori hispalensis episcopi: etymologiarum sive originum libri xx. Ed. W. M. Lindsay, 2 v. Oxford: Clarendon Press, 1962.

JACQUART, Danielle; THOMASSET, Claude. Sexuality and medicine in the middle ages. Trad. M. Adamson. Cambridge: Polity Press, 1988.

JEROME, St. Letter 22, to Eustochium. In: The principal works of St Jerome. Ed. P. Schaff e trad. W. H. Fremantle. Christian Classics Ethereal Library, Nicene and Post-Nicene Fathers, series II, v. 6. Grand Rapids, Michigan: WM. B. Berdmans Publishing Company, 1892, p. 100-137. Disponível em: http://www.ccel.org/ccel/schaff/npnf206.pdf Acesso em: 07 jun. 2018.

Letter 77, to Oceanus. In: The principal works of St Jerome. Ed. P. Schaff e trad. W. H. Fremantle. Christian Classics Ethereal Library, Nicene and Post-Nicene Fathers, series II, v. 6. Grand Rapids, Michigan: WM. B. Berdmans Publishing Company, 1892, p. 391-402. Disponível em: http://www.ccel.org/ccel/schaff/npnf206.pdf Acesso em: 07 jun. 2018.

Against Jovinian. In: The principal works of St Jerome. Ed. P. Schaff e trad. W. H. Fremantle. Christian Classics Ethereal Library, Nicene and Post-Nicene Fathers, series II, v. 6. Grand Rapids, Michigan: WM. B. Berdmans Publishing Company, 1892, p. 779-907. Disponível em: http://www.ccel.org/ccel/schaff/npnf206.pdf Acesso em: 07 jun. 2018.

JUVENAL. Satire VI. In: The satires of Juvenal. Trad. R. Humphries. Bloomington: Indiana University Press, 1958.

MARBODUS REDONENSIS EPISCOPUS. De meretrice. In: MIGNE, Jacques-Paul. Patrologiae cursus completus, Liber decem capitulorum. Series latina. Paris: 1844-1890, 171, cols. 1698-1699. Disponível em:

http://www.documentacatholicaomnia.eu/02m/10351123,_Marbodus_Redonensis_Episcopus, _Liber_Decem_Capitulorum,_MLT.pdf Acesso em: 07 jun. 2018.

MAP, Walter. The letter of Valerius to Ruffinus, against marriage .(Dissuasio Valerii ad Ruffinum philosophum nec uxorem ducat). In: De nugis curialium, courtiers' trifles. Ed. e trad. M. R. James, rev. C.N.L. Brooke and R. A. B. Mynors. Oxford: Clarendon Press, 1983. p. 287-331.

OVID. Amores. In: Ovid: the erotic poems. Trad. P. Green. Harmondsworth: Penguin, 1982.

Ars amatoria. In: Ovid: the erotic poems. Trad. P. Green. Harmondsworth: Penguin, 1982.

Heroides, amores; art of love, cosmetics, remedies for love, ibis, walnut-tree, sea fishing, consolation; metamorphoses; fasti; tristia, ex ponto. Goold, G.P., et alii (eds.), vols. I-VI. Loeb Classical Library. Cambridge, Mass. / London: HUP, 1977-1989. 
The cures for love (remedia amoris). Trad. A. S. Kline, 2001. Disponível em: http://www.poetryintranslation.com/PITBR/Latin/CuresforLove.php. Acesso em: 07 jun. 2018.

VIRGÍLIO. Eneida. Trad. José Victorino Barreto Feio e José Maria da Costa e Silva. São Paulo: Martins Fontes, 2004.

WALTHER, Hans. Proverbia sententiaeque latinitatis medii aevi. 9 vols. Göttingen: Vandenhoeck and Ruprecht, 1963-1969. 